\title{
LOPHIARIS TAPIAE, A NEW SPECIES IN THE LOPHIARIS OERSTEDII COMPLEX (ORCHIDACEAE) FROM THE YUCATAN PENINSULA, MEXICO
}

\author{
Ricardo Balam ${ }^{1,3}$ Germán Carnevali $^{1}$, William Cetzal-IX ${ }^{2} \&$ Rodrigo Duno ${ }^{1}$ \\ ${ }^{1}$ Centro de Investigación Científica de Yucatán, A. C., Herbario CICY, Calle 43 \\ núm. 130, Colonia Chuburná de Hidalgo, 97200 Mérida, Yucatán, México. \\ ${ }^{2}$ El Colegio de la Frontera Sur, Unidad Chetumal, Avenida del Centenario, km 5.5, \\ 77000 Chetumal, Quintana Roo, México. \\ ${ }^{3}$ Corresponding author: rbn696@hotmail.com
}

\begin{abstract}
Lophiaris tapiae Balam \& Carnevali (Orchidaceae: Oncidiinae) is described and illustrated. The new species is known only from the Escarcega area, and the Candelaria and Palizada rivers margins in the state of Campeche, Mexico. It is compared with species of the Lophiaris oerstedii complex, particularly with $L$. andrewsiae, to which it is closely related. A distribution map for the species and an identification key for all taxa of the L. oerstedii complex are included. We propose an "in danger of extinction" (P) conservation status for $L$. tapiae when assessed against the Method for Evaluation of Risk of Extinction for Mexican Wild Species (MER) criteria.
\end{abstract}

Key words: Campeche, endemic species, Lophiaris, Mexico, Oncidiinae, Orchidaceae.

\section{RESUMEN}

Se describe e ilustra a Lophiaris tapiae Balam \& Carnevali (Orchidaceae: Oncidiinae). La nueva especie se conoce solamente del área de Escárcega y de los márgenes de los ríos Candelaria y Palizada en el estado de Campeche, México. Se compara con los representantes del complejo Lophiaris oerstedii, particularmente con L. andrewsiae, con la que se encuentra cercanamente relacionada. Se incluye un mapa de distribución de las especies y una clave de identificación para todos los taxa del complejo L. oerstedii. De acuerdo con los criterios del 
Método de Evaluación del Riesgo de Extinción de las Especies Silvestres en México (MER) se propone el estado de conservación en "peligro de extinción (P)" para L. tapiae.

Palabras clave: Campeche, especie endémica, Lophiaris, México, Oncidiinae, Orchidaceae.

\section{INTRODUCTION}

The Lophiaris carthagenensis complex, as recognized by Balam (2007), includes four species: L. andrewsiae R. Jiménez \& Carnevali, L. oerstedii (Rchb. f.) R. Jiménez, Carnevali \& Dressler, L. teaboana R. Jiménez, Carnevali \& Tapia-Muñoz, and L. carthagenensis (Jacq.) Braem (Fig. 1A-D). Only the last one occurs in South America while the first three are restricted to Mexico and Central America. However, phylogenetic analyses performed with the use of nucleotide sequences of both nuclear (ITS) and plastid ( $p s b A-t r n H$, matK-trnK, trnL-F, trnL-rpl32) DNA (Balam in prep., data unpublished) have shown that L. carthagenensis, albeit morphologically similar to its Central American counterparts, is related to a cluster of South American taxa (L. lanceana (Lindl.) Braem and L. nana (Lindl.) Braem), and not to its Central American "look-alikes". Thus, in the forthcoming discussion, we will refer to Central American taxa similar to L. carthagenensis as the L. oerstedii complex, since this is the oldest name available in this group of taxa (Fig. 1B-D). The $L$. oerstedii complex is characterized by flowers that are mainly pink, rose, or pale lilac to purple, variously red-purple spotted or, more rarely, immaculate. The flowers are medium sized (16-28 mm diameter) when compared to other members of the genus. Also, the proportions of the labellum in taxa of the complex are distinctive, since the central lobe width and the length across the spread lateral lobes are of about the same dimensions (Fig. 1G4, G5). Simultaneously, the isthmus associated to these floral segments is generally narrow, about $1 / 3-1 / 5$ of the central lobe width. The calli are variously shaped but usually feature five teeth. Typically, the callus in the taxa of this complex consists of a structure with two proximal teeth (these smooth or with smaller teeth at each side), two distal teeth, and a longitudinal keel joining the two series of teeth, ending itself in a large, protuberant tooth between the two distal ones, resulting in a more or less 3-toothed apical structure (Fig. 1G1-G3). Lophiaris carthagenensis, albeit similar to the members of the L. oerstedii complex, can be morphologically diagnosed by a massive, "brain-like", more complex callus (see Fig. 1A, key and Table 1). 
Balam et al.: Lophiaris tapiae, a new species of Orchidaceae from the Yucatan Peninsula, Mexico

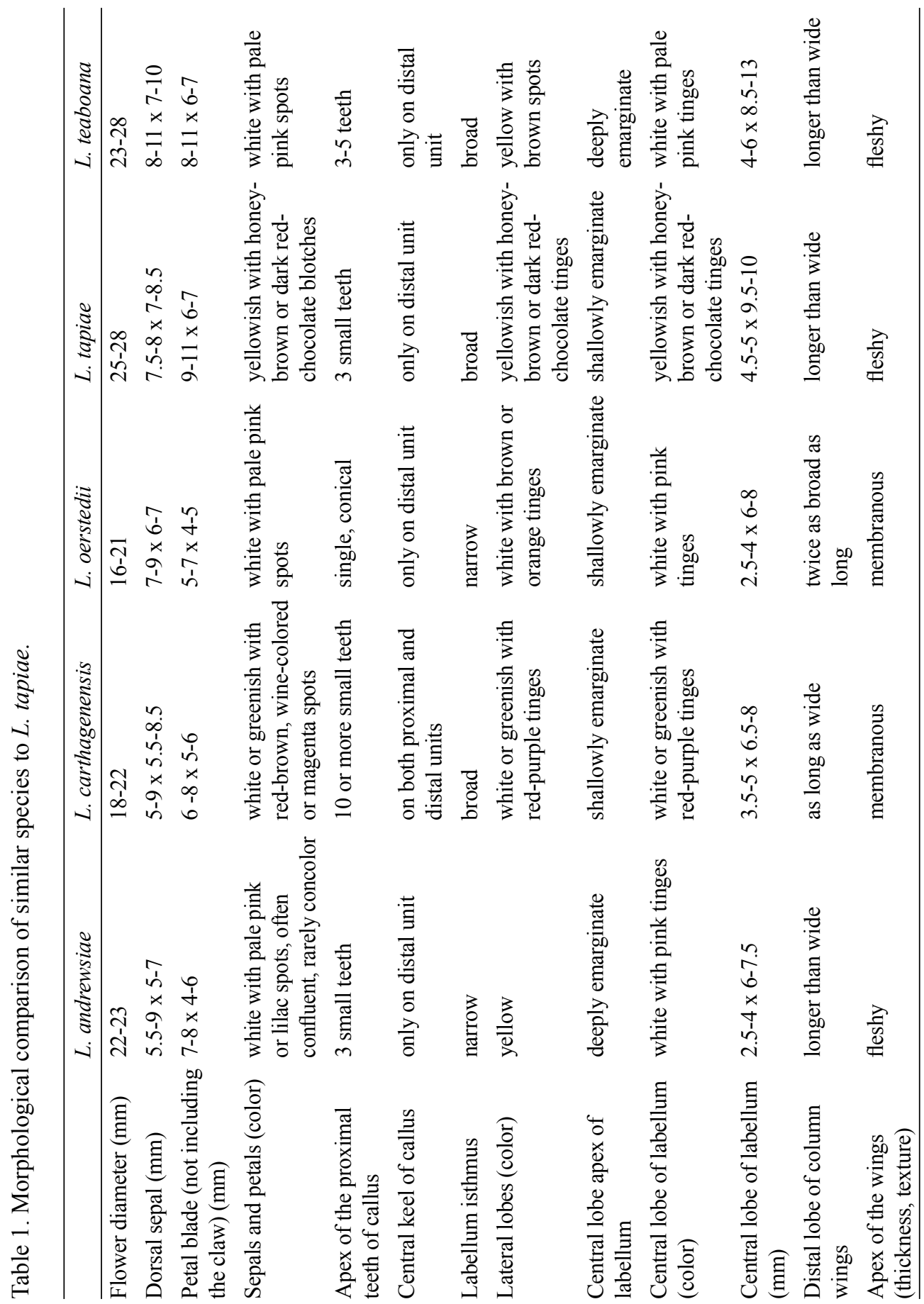




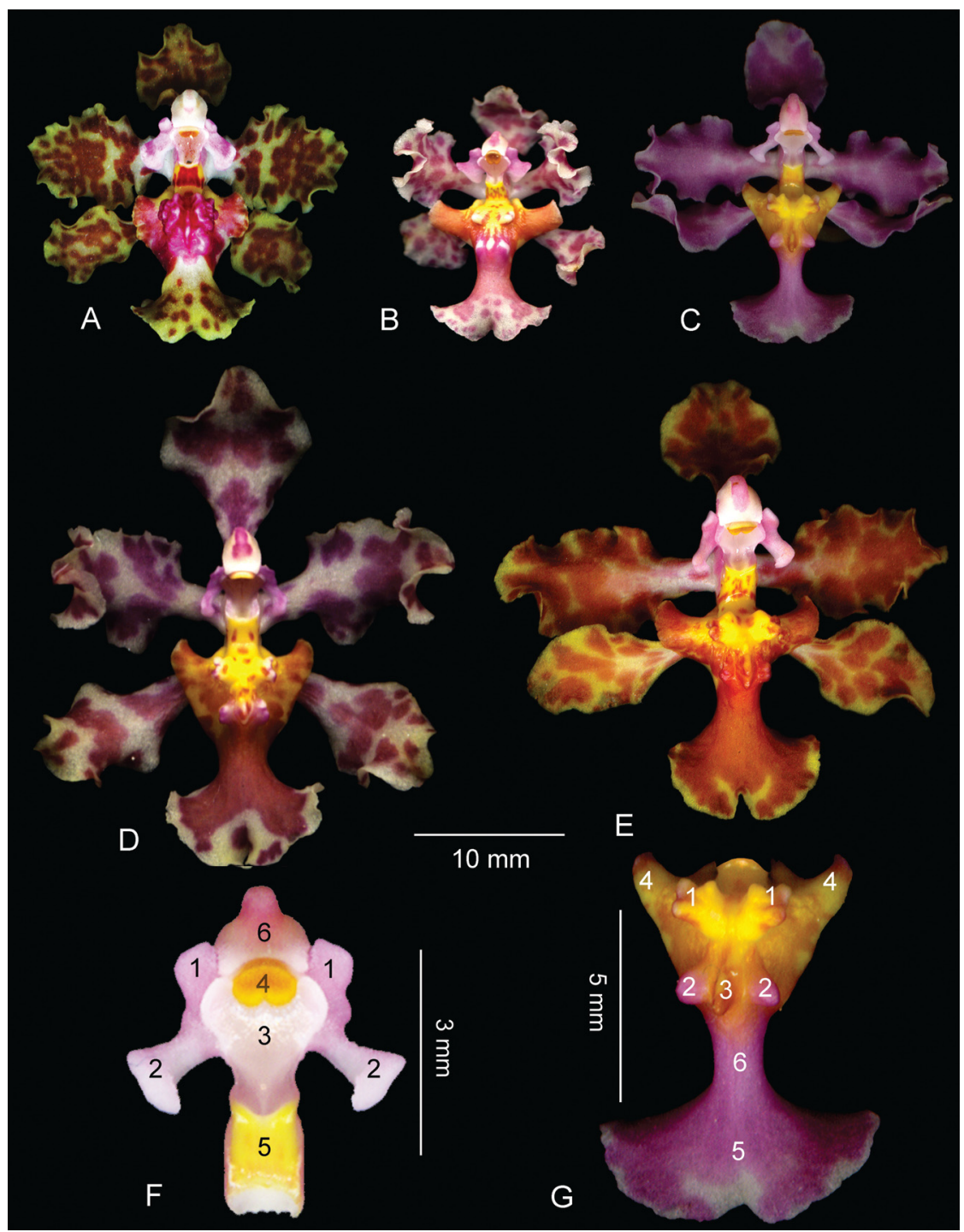

Fig. 1. A-E. Morphological comparison of Lophiaris carthagenensis and the L. oerstedii complex. A. L. carthagenensis; B. L. oerstedii; C. L. andrewsiae; D. L teaboana; E. L. tapiae; F. Column of L. andrewsiae: F1. proximal lobe of column wings, F2. distal lobe of column wings, F3. stigmatic cavity, F4 pollinarium, F5. tabula infrastigmatic, F6. anther cap; G. Labellum of L. andrewsiae: G1. proximal teeth of callus, G2. distal teeth of callus, G3. central keel of callus, G4. lateral lobes of labellum, G5. central lobe of labellum, G6. labellum isthmus. A. Based on G. Carnevali 7218 (CICY). B. Based on R. Balam s.n. C, F-G. Based on Cetzal s.n. (CICY). D. Based on L. Ibarra s.n. (CICY). E. Based on R. Balam et al. 114 (CICY). Scale: A-E. 10 mm. F. $3 \mathrm{~mm}$. G. $5 \mathrm{~mm}$. Assembled by W. Cetzal and R. Balam. 
Mexico harbors the highest diversity of Lophiaris Raf. species, 15 of the 23 species so far described. Of these, L. andreana (Cogn.) R. Jiménez \& Carnevali, L. andrewsiae, L. cosymbephora (C. Morren) R. Jiménez \& Carnevali, L. lindenii (Brongn.) Braem, L. lurida (Lind1.) Braem, L. oerstedii, L. teaboana, and the new species here proposed, are restricted to the tropical lowlands (below $1000 \mathrm{~m}$ ) of the southern states of Mexico (Veracruz, Oaxaca, Tabasco, Chiapas, Campeche, Yucatan, and Quintana Roo). Of these seven species, three are members of the Lophiaris oerstedii complex. The first one, Lophiaris andrewsiae is restricted to the north of the Yucatan Peninsula in Mexico, growing in dry seasonal forest, where the tropical dry forest interfaces with the tropical subdeciduous forests with precipitations under $1400 \mathrm{~mm}$. Secondly, Lophiaris oerstedii grows in northern Chiapas, SE Oaxaca, Tabasco (on the Gulf Coastal Plain), extending into the southern portions of the Yucatan Peninsula in Mexico, southwards into NW Costa Rica, always in medium-statured subperennifolious forest and tropical rainforests. Thirdly, Lophiaris teaboana is known from a narrow belt of tropical rainforest extending from NW Chiapas into SE Quintana Roo in Mexico. However, during the course of field work aimed at understanding the distributional patterns and variation of the Lophiaris oerstedii complex, we collected samples of plants morphologically similar to $L$. andrewsiae but differing in ecological preferences, flower color and size, and column wing shape. This we herein propose as a new species, thus becoming the fourth known member of the complex.

Lophiaris tapiae Balam \& Carnevali, sp. nov. (Figs. 1E, 2).

Species haec Lophiaris andrewsiae affinis, sed floribus majoribus (diametro 25-28 mm vs. 19-22 mm), labello longiore (11-12 mm vs. 7-9 mm), sepalis petalisque flavi-olivaceis, brunneo maculatis (vs. albis vel roseis, purpureo vel roseo maculatis), lobis lateralibus brunneo infusis (vs. flavis), isthmo latiore, apice lobi centralis pauce emarginato (vs. profunde emarginato) recedit.

Epiphytic herb, 29 to $32 \mathrm{~cm}$ tall not including the inflorescences; pseudobulbs clustered, subcylindrical, compressed, 5.5 to $20.5 \mathrm{~mm}$ long, 4.5 to $15 \mathrm{~mm}$ wide, green, clothed by 4 triangular to narrowly triangular sheaths, acute to acuminate, scarious-papyraceous, lacking a foliar blade, deciduous; leaf solitary, at the apex of the mature pseudobulb, conduplicate, oblong to oblong-elliptic, acute, fleshy, 6 to 29 cm long, ca. 24 to $36 \mathrm{~mm}$ wide near the base, $40-44 \mathrm{~mm}$ in the middle, $40-41 \mathrm{~mm}$ near the apex; inflorescence originating from the base of the pseudobulb, one per 


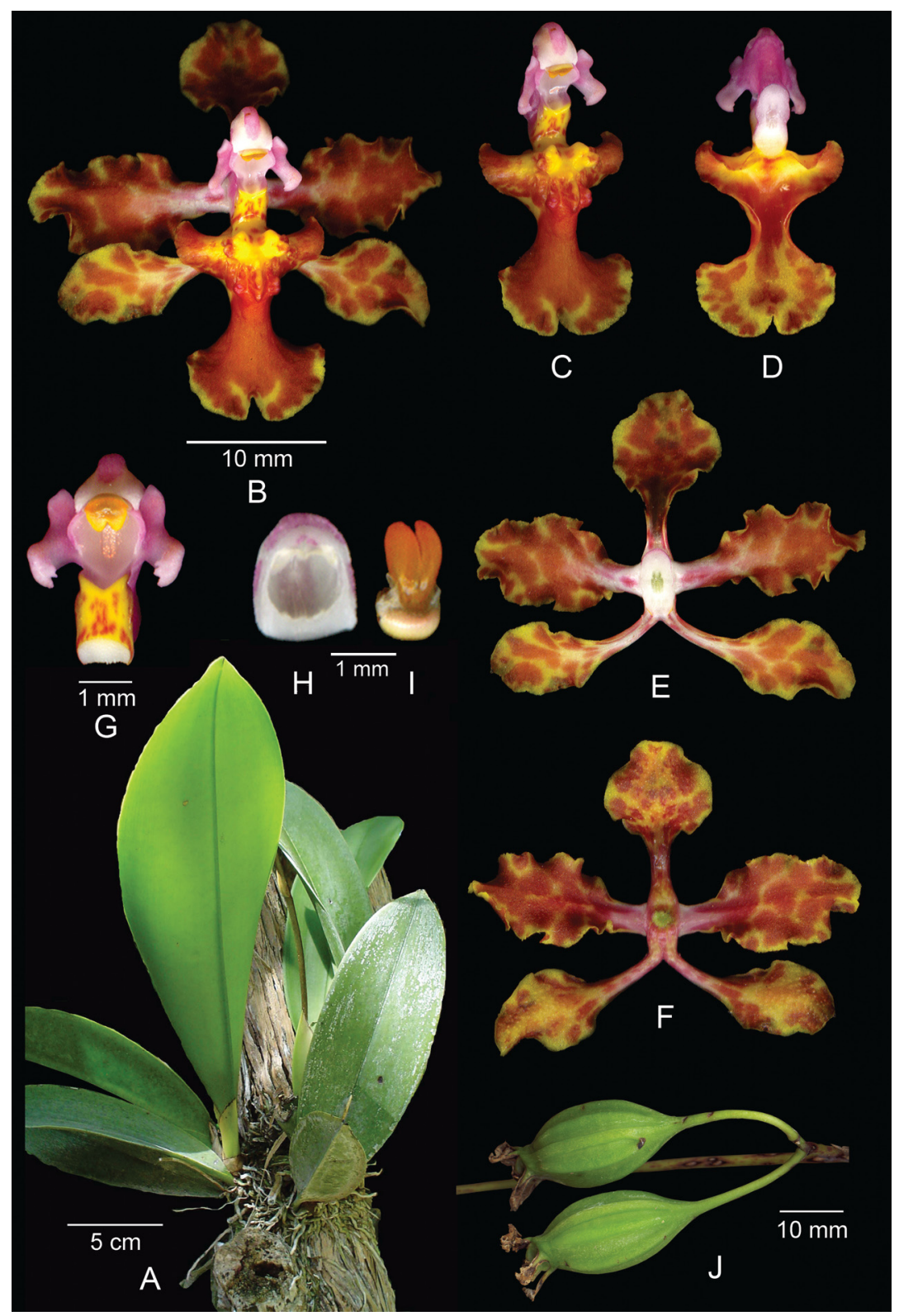

Fig. 2. Lophiaris tapiae. Based on R. Balam et al. 114 (CICY). A. Habit with partial inflorescence; B. Whole flower, front view; C-D. Labellum with column, front and back views; E-F. Sepals and petals, front and back views; G. Column, front view; H. Anther cap, front view; I. Pollinarium; J. Fruit. Scale: A. 5 cm. B-F, J. $10 \mathrm{~mm}$. G-I. $1 \mathrm{~mm}$. Assembled by W. Cetzal and R. Balam. 
pseudobulb, paniculate, ca. 16-51 cm long, with 8-15 flowers opening more or less simultaneously; floral bracts cucullate, triangular, semi-amplexicaul, $5 \mathrm{~mm}$ long, 2-2.5 mm wide; ovary pedicellate, sulcate, 7-8 mm long, 1.5-2.5 wide, pedicel 28-30 $\mathrm{mm}$ long; flowers resupinate, $25-28 \mathrm{~mm}$ diameter, overall base color of tepals and labellum yellowish with intense honey-brown continuous blotches or with confluent dark red-chocolate spots resulting in a totally red-brown flower, perianth segments of the right side of the flower spreading at $90^{\circ}$ to the main axis of the flower, thus parallel or subparallel to each other; dorsal sepal concave, orbicular, margins undulate, 7.5-8 mm long, 7-8.5 mm wide, clawed, claw 4-4.5 mm long, $2 \mathrm{~mm}$ wide; lateral sepals ovate, rounded, margins undulate, $7-8 \mathrm{~mm}$ long, $5 \mathrm{~mm}$ wide, clawed, claw $4 \mathrm{~mm}$ long, $2 \mathrm{~mm}$ wide; petals obovate, margins revolute and undulate, 9-11 $\mathrm{mm}$ long, 6-7 $\mathrm{mm}$ wide, shortly clawed, claw 4-5 $\mathrm{mm}$ long, 3-4 mm wide; labellum 11-12 $\mathrm{mm}$ long, 3-lobed, pandurate, forming an $135^{\circ}$ angle to the column; lateral lobes subtriangular to oblong, margins rounded, 7-8 $\mathrm{mm}$ long across when spread; central lobe transversely reniform and shallowly emarginated at the apex, $4.5-5 \mathrm{~mm}$ long, 9.5-10 mm wide; isthmus broad, $4 \mathrm{~mm}$ long, $3 \mathrm{~mm}$ wide; callus made up of 5 truncate independent teeth, proximally with two teeth that are high, thick, and erect, their apex composed of 3 small teeth; distally made up of two smaller teeth, with the apex of each one of them composed of 2-3 small teeth; the central teeth or keel emerges between the two distal teeth, thus, the distal section of the callus is 3-toothed; column thick, proportionally high, $4 \mathrm{~mm}$ long, white and pink, the tabula infrastigmatic prominent, sub-quadrate, yellow or orange-yellow with reddish spots, column wings dolabriform, broad, thin in texture, the apex of the distal lobe descendent and fleshy, 2.5 to $3 \mathrm{~mm}$ long, white and pink; anther cap subquadrate, with a truncate base and round apex, $2.5 \mathrm{~mm}$ long, $3 \mathrm{~mm}$ wide, with a central keel, papillose, white or pale pink, cavity bilocular, with a revolute rim; pollinarium composed of two obovate-elliptic pollinia, $2.5 \mathrm{~mm}$ long, sulcate, the stipe short, laminar, translucent and white, the viscidium horse shoe-shaped, brownish, the clinandrium triangular, white; stigmatic cavity triangular, white; capsules ellipsoid, 25-27 mm long, 12-14 mm wide.

Type: México, Campeche, municipio Candelaria, en la periferia del poblado de Candelaria, específicamente a $25 \mathrm{~m} \mathrm{NE}$ del puente, creciendo sobre árboles a orillas del río Candelaria, remanentes de selva mediana subperennifolia, $18^{\circ} 11^{\prime} 15.20^{\prime \prime} \mathrm{N}$, 91 ${ }^{\circ}$ '55.57" W, 35 m, floreciendo en cultivo en Mérida, Yucatán, México el 9 de noviembre de 2009 de una planta colectada el 21 de julio de 2009, R. Balam, W. Cetzal \& G. Cáceres 114 (holotype, CICY; isotypes, AMES, MEXU). 
The description was prepared from fresh material obtained from plants collected at the type locality, as well as from herbarium specimens and pickled material prepared from the additional specimens here cited. Photographs and scanned imagery of the species also contributed to this description.

Eponomy. Dedicated to José Luis Tapia-Muñoz, of Herbarium CICY, who has made important contributions to the knowledge of the Yucatan Peninsula flora and who, along with one of the authors of this paper, was the first to collect this species.

Paratypes. México, Campeche, municipio Candelaria, río Candelaria, lugar llamado "Dos Arroyos", ca. $30 \mathrm{~km}$ al SE de la población de Candelaria, 18¹0'76" $\mathrm{N}, 90^{\circ} 54^{\prime} 53^{\prime \prime} \mathrm{W}$, dos brazos colaterales de río con poca corriente; selva riparia con elementos de "tintal" y "pucteal" con relativa baja diversidad en el sotobosque y dosel y mediana diversidad de epífitas, con árboles de 5-15 m; floreciendo en cultivo en Mérida, Yucatán, México el 17 de Octubre de 2000 de una planta colectada el 17 Mayo del 2000, G. Carnevali, J. L. Tapia, F. May-Pat, L. Carrillo, D. Mondragón, P. Álvarez \& L. Martínez 6244 (AMES, AMO, CICY); same locality, floreciendo en cultivo en Mérida en el Jardín Botánico Regional del CICY el 13 de Noviembre de 2000, G. Carnevali, J. L. Tapia, F. May-Pat, L. Carrillo, D. Mondragón, P. Álvarez \& L. Martínez 6278 (CICY, SEL); same locality, floreciendo en cultivo en Mérida, Yucatán, México el 1 de Octubre de 2001, G. Carnevali 6416 (AMES, AMO, CICY, NY); same locality, floreciendo en cultivo en Mérida, Yucatán, México el 27 de Junio de 2003, G. Carnevali 7436 (AMES, AMO, CICY); municipio Candelaria, ca. $8 \mathrm{~km}$ al SE de Candelaria, sobre árboles a orilla del río Candelaria, selva mediana subperennifolia, $18^{\circ} 8^{\prime} 23.09^{\prime \prime} \mathrm{N}, 91^{\circ} 1^{\prime} 8.28^{\prime \prime} \mathrm{W}, 30 \mathrm{~m}$, floreciendo en cultivo en Mérida, Yucatán, México el 11 de Noviembre de 2009 de una planta colectada el 22 de Julio de 2009, R. Balam, W. Cetzal \& G. Cáceres 115 (CICY).

Distribution and habitat. Lophiaris tapiae has only been detected growing on trees found along the margins of the Candelaria and Palizada rivers in SW Campeche state (Fig. 3). Here it is where the Biotic Province of Yucatan Peninsula joins the coastal plain of the Gulf of Mexico (Carnevali et al., 2003). This new species grows in tall gallery forest within a general matrix of medium-statured subperennifolious forest. Here, it is locally common but the forests of the area are currently severely threatened by agricultural and ranching developments. 


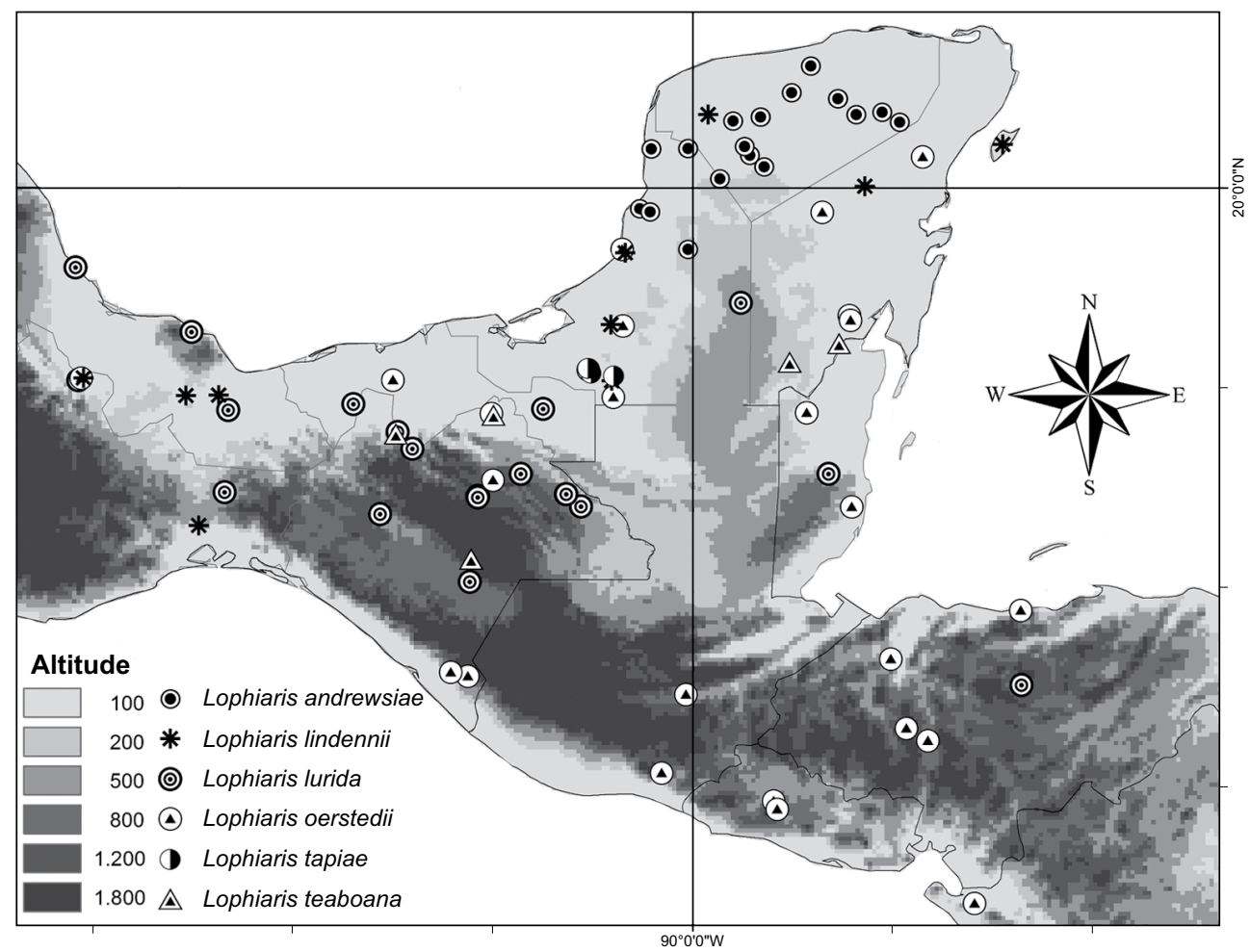

Fig. 3. Distribution of Lophiaris tapiae and related species of the southern states of Mexico.

Lophiaris tapiae is also known to us from photographs provided by Antonio Sánchez Martínez of Instituto Nacional de Investigaciones Forestales, Agrícolas y Pecuarias (INIFAP-Campeche). These images (not reproduced here) depict at least two different color morphs of what is certainly the same species from the Palizada river and the El Tormento/Escarcega area. The Escarcega plants are similar to the material we collected along the Candelaria river margins but with smaller, more laxly arranged honey-brown spots, resulting in an overall yellower flower. The Palizada plants feature large, confluent dark red-chocolate spots resulting in a totally red-brown flower. Actual materials of these two areas were not available to us for measurements and DNA sequencing, but the overall morphology and color patterns of the flowers, as well as their immediate geographical proximity, leave no doubt as to their conspecificity with the Candelaria River plants. 
MER Risk criteria. We determined the risk status of this new species through the Method for Evaluation of Risk of Extinction for Mexican Wild Species (MER) (Anónimo, 2002), because it has been required by Mexican law since 2002 for listing organisms for protection. This method provides a reasonably reliable way to identify species of conservation concern and meets the goals of facilitating timely conservation decisions and generating testable hypotheses for future studies (Tambutti et al., 2001). Lophiaris tapiae is known from three localities restricted to the margins of the Candelaria and Palizada rivers in SW Campeche, thus occurring in less than 5\% (actually less than 1\%) of the Mexican territory. Based on an in situ assessment, the species grows at low population densities. Upon assessing the conservation status of the new taxon against the MER criteria, it scores 12 points, which places Lophiaris tapiae in the $\mathbf{P}$ status, "in danger of extinction" ("en peligro de extinción").

Diagnostic features. The morphologically similar but unrelated Lophiaris carthagenensis is distributed from SE Costa Rica into northern Colombia and Venezuela, where it grows in a variety of humid and seasonally dry forests. Lophiaris tapiae is morphologically similar to the other species of the L. oerstedii complex. Among these species, L. tapiae is phenetically closer to L. andrewsiae, from which it can be distinguished by the larger flowers $(>25 \mathrm{~mm}$ diameter with a labellum 11-12 $\mathrm{mm}$ long vs. $<23 \mathrm{~mm}$ diameter with a labellum $7-10.5 \mathrm{~mm}$ long in L. andrewsiae), color (yellowish with intense honey-brown continuous blotches or with confluent dark red-chocolate sports vs. pale rose base color, lilac, purple or deep pink spotted in L. andrewsiae), and the structure of the callus (see table 1 for a morphological comparison between the new species and the other members of the complex).

The possibility of a hybrid origin of this new species is here dismissed. Only Lophiaris lindenii, L. lurida, and L. oerstedii are known to occur in the general area where this new species is found. Natural hybrids involving all possible combinations of these species are already known and their floral morphologies are easily discernible and different from L. tapiae. The hybrid between $L$. lindenii and L. oerstedii is featured in page 129 (figure 265) of Hágsater et al. (2005). The two possible hybrids involving $L$. lurida (which has not been collected within a 100 $\mathrm{km}$ ratio of the known localities of $L$. tapiae) display the large, transversely oblong central lobe of this species resulting in a broader than wide labellum, thus making them readily distinguishable from $L$. tapiae, whose labellum is conspicuously longer than wide. 
Key to the species of the Lophiaris oerstedii complex

The following key is intended for use with live, pickled, or dry specimens, albeit it works much better with the first two. In most cases, a flower in good conditions is required to obtain reliable determinations. Of particular importance is to have good information on flower color, especially of the labellum. Good photographs are also useful. With herbarium specimens, it may be necessary to rehydrate a flower to determine the position and structure of column wings and callus teeth. Good rehydration is obtained by boiling the flower for a few minutes and then let it absorb water for several hours (overnight is ideal). Even better is to soak the whole flower in either diluted ammonia for 20-30 minutes or for 3-5 minutes in concentrated ammonia; afterwards it should be rinsed/rehydrated in water for several hours until the material is fully turgid. When selecting floral material for rehydration and later observation, it is recommended to choose flowers placed on the herbarium sheet near leaves or the peduncle of the inflorescence; these flowers are less likely to have been squashed/crushed (and then irretrievably distorted) upon pressing. Although unrelated to members of this complex, we include Lophiaris carthagenensis in the key because it is morphologically similar to the species that comprise it.

1 The central keel of the labellum callus elongate, running from the base of the proximal teeth to the apex of the distal one, dividing thus lengthwise the two (right and left) teeth; the apex of the proximal teeth with 10-or-more small teeth (conferring to the whole structure a "brain-like" aspect); plants from SE Costa Rica into northern Colombia and Venezuela L. carthagenensis

1 The central keel of the labellum shorten, running across (and splitting) only through the distal teeth of the callus, thus, the distal section of the callus is 3-toothed; the apex of the proximal teeth of the callus with 3-5 small teeth; plants from SE Mexico (mainly SE of the Tehuantepec isthmus) southward into NW Costa Rica.

2 Flowers (23-)25-28 mm diameter.

3 Flowers yellowish with intense honey-brown continuous blotches or with confluent dark red-chocolate spots; perianth segments of the right side of the flower spreading at $90^{\circ}$ to the main axis of the flower, thus parallel or subparallel to each other; central lobe of the labellum yellowish with honey-brown or dark red-chocolate tinges; plants restricted to the Candelaria and Palizada rivers, Campeche, Mexico L. tapiae 
3 Flowers white with lilac or pink spots, rarely flowers concolor; perianth segments of the right side of the flower radiating at $45^{\circ}$ to the main axis of the flower (the lateral sepal at $45^{\circ}$ while the petal at $135^{\circ}$ ); central lobe of the labellum pale pink tinged; plants restricted to NW Chiapas and SE Quintana Roo, Mexico L. teaboana

2 Flowers 16-22(-23) mm diameter.

4 Proximal teeth of the callus low, conical, pointing downward; disk bright yellow and the lateral lobes of the labellum white or dull yellow, with brown or orange tinges; distal lobe of column wings twice as broad as long; labellum wider through the lateral lobes than through the spread central lobe; plants from SE Oaxaca, N Chiapas, Tabasco, and the Yuca$\tan$ Peninsula southward into NE of Costa Rica L. oerstedii

4 Proximal teeth of the callus 3-toothed at apex, pointing forward; disk and lateral lobes of the labellum bright yellow; distal lobe of column wings longer than wide; labellum wider through the spread central lobe than through the lateral lobes; plants restricted to the NW section of the Mexican Yucatan Peninsula

L. andrewsiae

\section{ACKNOWLEDGMENTS}

The authors would like to thank Gustavo A. Romero-González (AMES), Eliana Noguera Savelli (CICY, VEN), and Lizandro N. Peraza Flores (CICY), who critically reviewed and made suggestions for improving the manuscript. José Luis Tapia Muñoz (CICY) and Gabriel Cáceres who helped collect and process some of the records here documented. Lilia Can Itzá and Silvia Hernández Aguilar (CICY) provided valuable assistance in handling the herbarium specimens analyzed in this study and in gathering data required to properly document this article. Antonio Sánchez Martínez (Estación El Tormento, INIFAP-Campeche) provided digital photographs of two different color morphs of the same species from the El Tormento/Escarcega, and Palizada rivers, which proved useful to understand the variation and distribution of Lophiaris tapiae. We are grateful to CONACyT by scholarships numbers 167007 and 162579 for doctoral studies provided to the first and third author, respectively. CONACyT partially funded this project via grant 49980-Q ("Filogenia molecular y morfológica, revisión sistemática y una exploración de cuatro regiones no-codificantes del genoma del cloroplasto para estudios filogeográficos en el complejo Trichocentrum (Orchidaceae: Cymbidieae: Onci- 
diinae") awarded to G. Carnevali. Finally, we are grateful with two anonymous referees for valuable comments.

\section{LITERATURE CITED}

Anónimo. 2002. Norma Oficial Mexicana NOM-059-ECOL-2001. Protección ambientalEspecies nativas de México de flora y fauna silvestres. Categorías de riesgo y especificaciones para su inclusión, exclusión o cambio. Lista de especies en riesgo. Anexo normativo I, método de evaluación del riesgo de extinción de las especies silvestres en México MER. Secretaría del Medio Ambiente y Recursos Naturales, Diario Oficial de la Federación, segunda sección, 6 de marzo de 2002. México, D.F., pp. 1-81.

Balam, R. 2007. Sistemática y filogenia del género Lophiaris Raf. (Orchidaceae). M. S.

Thesis. Centro de Investigación Científica de Yucatán, A. C. Mérida, Yucatán, México. pp. 95.

Carnevali, G. I. Ramírez-Morillo \& J. A. González-Iturbe. 2003. Flora y vegetación de la Península de Yucatán. In: Colunga García-Marín, P. \& A. Larqué Saavedra (eds.). Naturaleza y sociedad del área maya: pasado, presente y futuro. Centro de Investigación Científica de Yucatán, A. C. Mérida, Yucatán, México. pp. 53-68.

Hágsater, E., M. A. Soto-Arenas, G. A. Salazar-Chávez, R. Jiménez-Machorro, M. A. López-Rosas \& R. L. Dressler. 2005. Las orquídeas de México. Instituto Chinoín. México, D.F. pp. 304.

Tambutti, M., A. Aldama, O. Sánchez, R. Medellín \& J. Soberón. 2001. La determinación del riesgo de extinción de especies silvestres en México. Gaceta Ecológica 61: 11-21. 